\title{
A review of Internet-based approaches for health promotion programs related to the COVID-19 pandemic and wellness education
}

\author{
Carissa Wityadarda, ${ }^{1}$ Gusti Ayu Sinta Deasy Andani, ${ }^{1,2}$ Rina Rostarina1,3,* \\ 'Biomedical Sciences, Faculty of Medicine Padjadjaran University, Bandung Indonesia \\ ${ }^{2}$ Physiology Department, Faculty of Medicine Jenderal Achmad Yani University, Cimahi, Indonesia \\ ${ }^{3}$ Central of Health Training, Public Health Office West Java, Indonesia
}

KEYWORDS COVID-19

Health promotion

Wellness

Internet

Self-efficacy

Self-management
ABSTRACT COVID-19 pandemic continues to have significant impacts in various sectors of society worldwide, including Indonesia. One major impact of COVID-19 occurs in the health information sector especially with social distancing regulations that inhibit people to access health care providers. This has led to several other problems such as behavior alteration involving unhealthy lifestyles and misleading information. Due to the limitations of social interaction, health care providers have proposed various methods to provide health promotions related to COVID-19 and wellness education that are accessible by the whole society with or without Internet access. This study aimed to review the current strategies of health information systems to increase knowledge about COVID-19 and overall wellness by implementation of Internet-based programs. This review is based on secondary study conducted with online search engines. Some previous studies showed that online training has improved knowledge significantly. Other research also described how the success of a community education program depends on adequate motivation and access to proper information. Three main factors that cause the failure of community education are lack of self-efficacy, lack of information, and distraction without proper supervision. Lack of information is due to difficulty to gain Internet access in some areas and for some populations. In conclusion, Internet-based approaches can be implemented for health promotion programs related to COVID-19 and wellness due to the massive growth of the Internet use in Indonesia.

(c) The Journal 2021. This article is distributed under a Creative Commons Attribution-ShareAlike 4.0 International license.

\section{Introduction}

The novel Coronavirus Disease 2019 (COVID-19) is caused by the pathogen identified as Severe Acute Respiratory Syndrome Coronavirus 2 (SARSCoV-2). ${ }^{1}$ COVID-19 has caused a pandemic with 115 million confirmed cases worldwide, including over 2.5 million deaths based on recent World Health Organization (WHO) data as of March 3, 2021.2 This condition causes a major problem on a multi sector basis, including the health and information sectors which should be benefiting by the digitalization era. ${ }^{3}$ Difficulties in accessing information continue to worsen with 'work from home' and 'online class' policies which are not applicable for everyone.

\footnotetext{
*Correspondence: rostarinarina@gmail.com

Central of Health Training, Public Health Office West Java, Indonesia, Jl. Pasteur No.31, Pasir Kaliki, Kec. Cicendo, Kota Bandung, Jawa Barat 40171
}

Policies aimed at preventing the spread of disease also limit people from gaining the direct information that they used to get from their school or health care providers. ${ }^{4}$ Moreover, the lack of information for these populations can seriously impact their overall health status including stress-induced home environment, alteration of dietary intake, physical inactivity, and less social interactions. ${ }^{5,6}$

Wellness education as an essential part of health promotion that is also negatively impacted during the COVID-19 pandemic is actually one of the key elements that needs to be done on a daily basis. One solution to face this challenge is using e-wellness programs that were used even before the COVID-19 pandemic. The improvement of wellness knowledge is proven to be effective to gain the basic information in maintaining overall health. ${ }^{7,8}$ For example, Guerrero in 2020 found that an intervention of educating parents about physical activity can increase 
the pupils' physical activity which correlates with their overall family fitness. Moreover, other online interventions to promote a healthy lifestyle such as diet and stress management are also beneficial to increase community understanding toward healthy lifestyles. ${ }^{9}$

Digitalization is often associated with the ease of accessing information and the use of gadgets. The user population of Smartphones in Indonesia particularly is categorized as the fourth largest active user group around the world, with over 250 million people in total. ${ }^{10}$ Almost 171.26 million out of Indonesia's total population of over 260 million are active Internet users. ${ }^{11}$ About $33 \%$ of Indonesia's population access the Internet regularly through their mobile devices and this number is likely to increase to $36 \%$ by $2023 .{ }^{11}$ Specifically, Muller in 2016 stated that Indonesians also rank third in the number of social media users in the Asia-Pacific region with $59 \%$ actively involved in social media. ${ }^{11}$ Those data demonstrate that there is an excellent opportunity for the Internet-based health promotion programs related to COVID-19 and wellness. This opportunity was further explained by the APJII and Pusat Kajian Komunikasi Universitas Indonesia (PusKaKom UI) in their 2015 survey that found $49 \%$ of Internet users were in the age range of $18-25$ years and $33.8 \%$ in the age of 26-35 years. Most of the people in this age category are typically more educated and productive members of society. ${ }^{3}$ Thus, they can be expected to have more influence on society.

This digital development gives both positive and negative impacts in society. When various information is widespread freely on the Internet, then we first need to filter and process before adapting and passing it on to others. The problem is many people have the wrong assumption about the accuracy of the free articles that can be read online without first checking the facts and immediately re-share it with a bigger audience. This causes the negative content and misleading information to be continuously spreading sporadically. One example is the misinterpretation of the study conducted by Oren et al., in 2020, which caused major confusion about chloroquine in disease management. ${ }^{12}$ Some misinterpretations of face masks, such as the material, how to use and when to wear also became an example of how information was not welldistributed among society. ${ }^{13}$

Information systems are fundamental for public education related to wellness and other health promotion programs during the COVID-19 pandemic. Accordingly, we summarized various methods used in Internet-based approaches of health promotions from e-programs and e-wellness education. These are designed to better cope with COVID-19 public health problems such as misleading information about COVID-19 and inactive lifestyle as a result of the lockdown during the pandemic. We then aimed to answer the study objective about which approaches were best suited and expected to be successfully implemented to society with or without Internet access.

\section{Method}

This review was conducted using the online search engines: PubMed and Google Scholar. Inclusion criteria for studies in this review were: articles about health promotion programs related to wellness intervention and COVID-19 informative knowledge. Exclusion criteria were: studies before 2010, review articles, and editorial notes. Exposure: research focus on health promotions related to healthy lifestyle and COVID-19. Outcomes: Studies that showed the impact of health promotions toward knowledge during COVID-19 pandemic; wellness interventions towards knowledge and behavior before the pandemic. Types of studies included in this review: Experimental studies and observational studies. Keywords of research: health promotion, COVID-19, wellness intervention, and knowledge.

\section{Results}

Based on the data from previous study, we defined two main results regarding these topics. First, we describe various data about health promotion strategies during the COVID-19 pandemic to overcome the transmission of the disease. Furthermore, we provide the data from various studies about wellness interventions as a part of health promotion programs.

Through the findings on the Tables 1 and 2 below, we propose the possible mechanisms of 


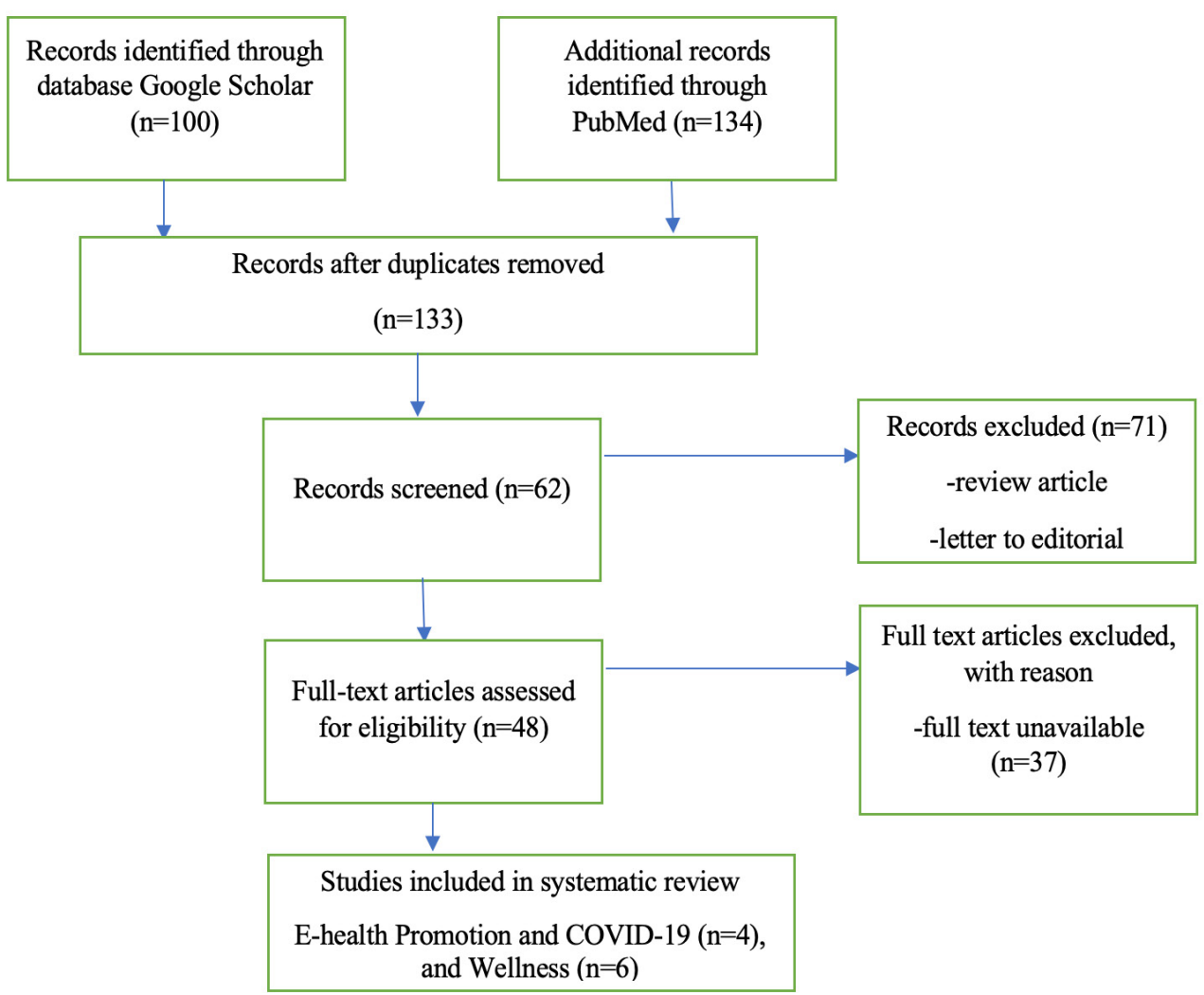

Figure 1. Preferred Reporting Items for Systematic Reviews and Analyses (PRISMA) chart of systematic review.

how Internet-based health education outlined in Figure 2 can promote a successful implementation through the determination of the participants, availability and capability of Internet access and time of intervention. Meanwhile, the major distractions of e-health promotion depend on the motivation of the participants, inability to access the Internet, lack of ability to operate the application, and distraction from family/working environment.

\subsection{E-health promotion program during COVID-19}

As shown in Table 2, social media is also beneficial to share proper information and avoid the spread of hoax or false news. Ahmed in 2020 conducted a social network and content analysis on Twitter about the $5 \mathrm{G}$ conspiracy theory related to COVID-19. This study showed that $65.2 \%(n=152)$ of tweets still have positive mindset against the conspiracy compared to only $34.8 \%$ who accommodate misleading information about the $5 \mathrm{G}$ conspiracy. It showed that the 'viral' \#5GCoronavirus hashtag did not represent the overall beliefs of people towards the conspiracy theory. ${ }^{14}$
Lin in 2020 conducted a survey about attitudes, knowledge, and anxiety levels of people in China towards COVID-19. Results showed that most of the participants have good knowledge about COVID-19 events though there was a knowledge gap about some signs and symptoms of COVID-19 infections. The study also informed that younger people are more likely to have anxiety which was indicated by stress tests, State-Trait Anxiety Inventory: STAI-S and STAI-T. The author suggested the importance of public communication to change people's knowledge and attitudes, especially mental health promotions during infectious disease outbreaks. ${ }^{15}$

Schillinger in 2020 conducted a study called The SPHERE Continuum Model to show that social media can influence public health concerning a contagion, inoculant, vector, media for surveillance, disease control and mitigation, and treatment. ${ }^{16}$ Those notions are also supported by a study conducted by Vandormael in 2020 about the use of the Gorilla ${ }^{\mathrm{TM}}$ platform to demonstrate and measure changes in behavioral intent towards five hygiene practices in 


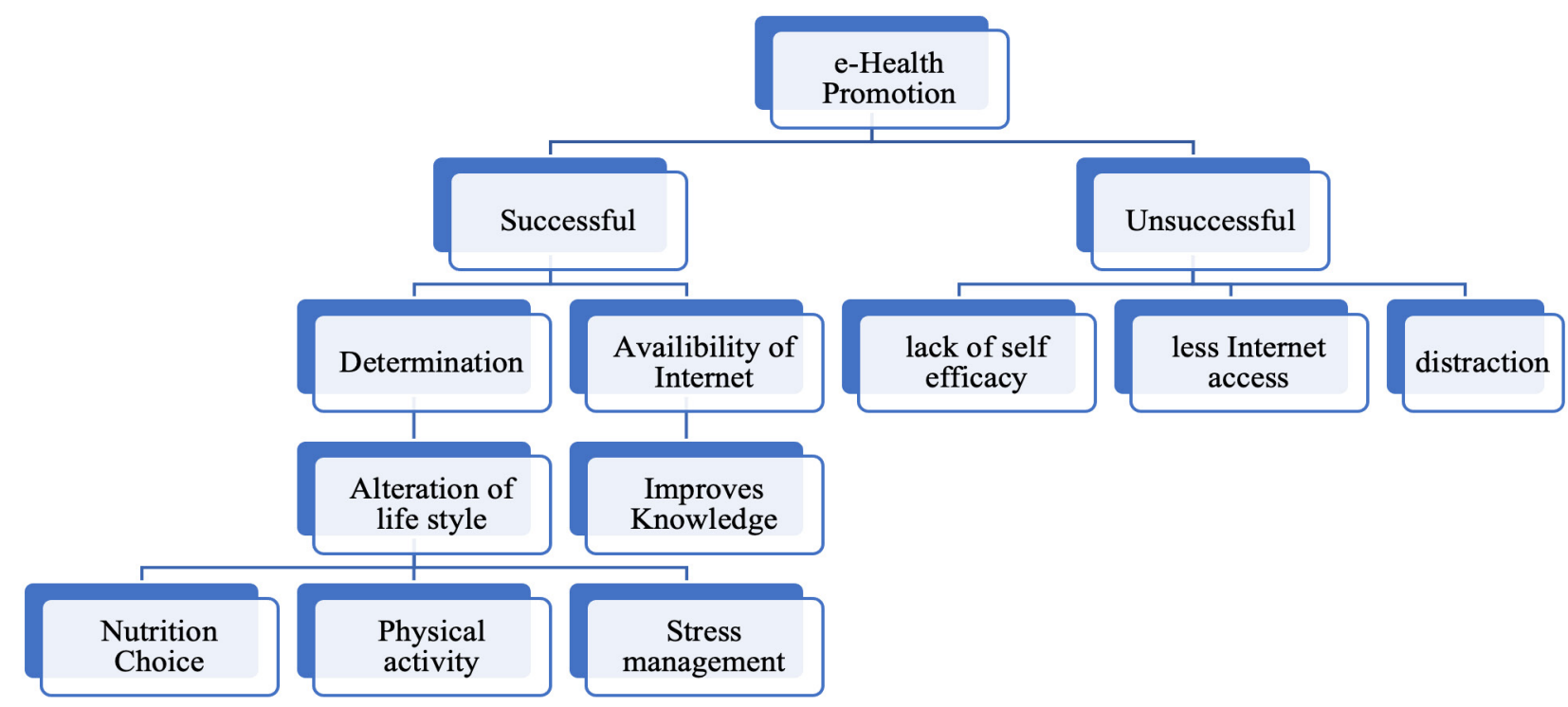

Figure 2. The proposed mechanisms of e-Health promotion determination based on successful and unsuccessful interventions.

their online participants. The secondary outcome of that program was to measure the knowledge about behaviors that can prevent the spread of COVID-19. ${ }^{17}$

Digitalization also provides the ease for people to do social interaction and information exchange without meeting in person. One of the methods was conducted by Meinert in 2020 with the ADAPT-CAFÉ program that make it possible for older people, their families and peers to improve their well-being and health during and after the pandemic. ${ }^{18}$

\subsection{Wellness intervention}

Lifestyle intervention as a part of health promotions such as described in Table 2 have greater impact on women populations especially women with special circumstances. For instance, Kazumi in 2020 conducted a study which highlighted the diet treatment with lifestyle modification intervention that showed a significant improvement on their subject's knowledge including eating habits, knowledge about Polycystic ovary syndrome (PCOS), and physical activity. Moreover, the bonding between healthcare service providers and their participants increased their satisfaction towards healthcare providers, and their overall experience with $p<0.05 .{ }^{7}$ We concluded that their satisfaction result is based on the criteria of their target PCOS participants included in the study.
Since our article aims to highlight health promotions, we found that the study by McNamara in 2008 had shown both online and offline e-health promotions have the same effect on promoting healthy lifestyle. Yet, this finding indicated there was improvement in their participants' knowledge but not weight reduction and activity level in the long term. ${ }^{19}$ Those two factors are difficult to follow if the intervention is only based on online methods since not everybody is equal in all measures such as internet availability, weight scale, and level of distraction which are confounding factors in real life situation. Meanwhile, the successful participants included in McNamara's study had higher willingness and motivation to improve their body image.

Meanwhile, Woerden in 2014 and AndersonBill in 2011 have shown different results from McNamara in 2008. ${ }^{19-21}$ It was because of the difference and more convenient application applied in the newest study. ${ }^{19-21}$ Woerden in 2014 has shown that online training with the self-reporting method had an increase of fiber intake, improvement of physical activity scale, and improvement of selfstress control. Moreover, Ebert in 2016 supported Woerden's findings in 2014 by providing data that online Internet-based and mobile-based stress management (iSMI) can reduce their participants' overall stress..$^{8,20}$ 
Table 1. The example of social media application in health knowledge during COVID-19

\begin{tabular}{|c|c|c|c|c|c|}
\hline Author & Subjection & Study Population & $\begin{array}{l}\text { Time of } \\
\text { the study }\end{array}$ & Method & Result(s) \\
\hline Ahmed $^{14}$ & $\begin{array}{l}\text { Social platform } \\
\text { analysis toward } \\
\text { conspiracy } \\
\text { theory related } \\
\text { to COVID-19 and } \\
\text { how to deal with } \\
\text { misinformation }\end{array}$ & $\begin{array}{l}\mathrm{N}=233 \text { tweeter } \\
\text { feeds with } \\
\# 5 G \text { Coronavirus } \\
\text { hashtag }\end{array}$ & 7 days & $\begin{array}{l}\text { Social } \\
\text { network } \\
\text { analysis } \\
\text { and content } \\
\text { analysis on } \\
\text { Twitter }\end{array}$ & $\begin{array}{l}\text { Total of } 233 \text { tweets that screened } \\
34.8 \%(n=81) \text { provide misleading } \\
\text { information about } 5 G \text { conspiration. } \\
\text { Meanwhile, } 65.2 \% \text { ( } n=152 \text { ) of } \\
\text { tweets still have positive mindset } \\
\text { against conspiracy. }\end{array}$ \\
\hline $\operatorname{Lin}^{15}$ & $\begin{array}{l}\text { Population based } \\
\text { survey including } \\
\text { attitudes, } \\
\text { knowledge, and } \\
\text { anxiety levels of } \\
\text { people in China } \\
\text { towards COVID-19 }\end{array}$ & $\begin{array}{l}\mathrm{N}=2,446 \\
\text { residents of } \\
\text { mainland China } \\
\text { over the age of } \\
18 \text { years }\end{array}$ & $\begin{array}{l}1 \text { month } \\
\text { (30 days } \\
\text { period) }\end{array}$ & $\begin{array}{l}\text { Cross } \\
\text { sectional } \\
\text { research }\end{array}$ & $\begin{array}{l}\text { Almost } 86.7 \% \text { of respondents } \\
\text { skeptical of being infected. } \\
\text { Meanwhile, other groups in survey } \\
\text { have a perception to be already } \\
\text { infected with } 67 \% \text {. } \\
\text { A knowledge gap in the signs and } \\
\text { symptoms of COVID-19 infections, } \\
\text { namely runny nose ( } 54.5 \%) \text {, } \\
\text { diarrhea ( } 66.4 \%), \text { headache } \\
\text { (68.9\%), and sore throat ( } 77.5 \%) \\
\text { was found. The mean and standard } \\
\text { deviation (SD) for the total } \\
\text { knowledge score was } 20.3 \text { (SD } \pm \\
2.9)\end{array}$ \\
\hline Vandormael $^{16}$ & $\begin{array}{l}\text { Measure primary } \\
\text { and secondary } \\
\text { outcomes related } \\
\text { to COVID-19 } \\
\text { hygiene that reduce } \\
\text { the chances of } \\
\text { being infected or } \\
\text { spreading with } \\
\text { COVID-19 }\end{array}$ & $\begin{array}{l}\text { Gorilla }^{\mathrm{TM}} \text { platform } \\
\text { is used to } \\
\text { recruit online } \\
\text { participants }\end{array}$ & - & $\begin{array}{l}\text { Multi-site, } \\
\text { parallel } \\
\text { group, } \\
\text { randomized } \\
\text { controlled } \\
\text { trial (RCT) }\end{array}$ & $\begin{array}{l}\text { As our primary outcome, we will } \\
\text { measure changes in behavioral } \\
\text { intent toward five hygiene } \\
\text { practices: social distancing, washing } \\
\text { hands, cleaning household surfaces, } \\
\text { not sharing eating utensils, and } \\
\text { not stockpiling essential goods. } \\
\text { As a secondary outcome, we } \\
\text { will measure knowledge about } \\
\text { behaviors that can prevent the } \\
\text { spread of COVID-19. }\end{array}$ \\
\hline Meinert ${ }^{17}$ & $\begin{array}{l}\text { Provide a tool for } \\
\text { older people and } \\
\text { their families and } \\
\text { peers to improve } \\
\text { their well-being and } \\
\text { health during and } \\
\text { after pandemics. }\end{array}$ & $\begin{array}{l}\text { Elderly with their } \\
\text { relatives }\end{array}$ & - & Case study & $\begin{array}{l}\text { Real time development of ADAPT- } \\
\text { CAFÉ program. }\end{array}$ \\
\hline
\end{tabular}

Finally, the successful results of e-wellness education as shown in Table 2 have shown a good potential result to combat the inactive lifestyle during the COVID-19 pandemic with special terms such as convenient web applications, well designed programs, Internet access, and willingness of participants. Although, these findings must be followed by future study to confirm the results especially during the COVID-19 conditions.

\section{Discussion}

This systematic review revealed that the use of the Internet as media to promote health information and wellness education can be successfully implemented through the 171.26 million out of 260 million active Internet users in Indonesia. Despite the high number of active Internet users in Indonesia, the Internet penetration rate of Indonesian is only 53.7 percent, which was lower than any other Asia-Pacific country in June 2019. ${ }^{11}$ These data show that almost half of the Indonesia population does not have Internet access to gain proper information in health-related 
Table 2. The relevant studies of wellness intervention in health promotion study populations

\begin{tabular}{|c|c|c|c|c|c|}
\hline Author & Subjection & $\begin{array}{l}\text { Study } \\
\text { population }\end{array}$ & $\begin{array}{l}\text { Time of } \\
\text { the study }\end{array}$ & Method & Result(s) \\
\hline Kazemi $^{(7)}$ & $\begin{array}{l}\text { Pulse based diet } \\
\text { and Therapeutic } \\
\text { Lifestyle } \\
\text { Changes }\end{array}$ & $\begin{array}{l}\text { Woman, age: } \\
18-35 \\
\mathrm{~N}=30 \text { in the } \\
\text { pulse-based } \\
\text { diet and } \mathrm{N}= \\
31 \text { in the TLC } \\
\text { diet groups }\end{array}$ & 16 weeks & $\mathrm{RCT}$ & $\begin{array}{l}\text { There is an increasing knowledge in healthy } \\
\text { eating, Polycystic ovary syndrome (PCOS) } \\
\text { knowledge, activity level, healthcare } \\
\text { satisfaction, feelings and experiences about } \\
\text { intervention, and health concerns, respectively } \\
(p<0.02) \text {, decreased weight }(r<-0.35) \text { and } \\
\text { homeostatic model assessment of insulin } \\
\text { resistance ( } r=-0.18) \text { correlated with increased } \\
\text { scores of PCOS knowledge; adherence to } \\
\text { intervention correlated with increased scores. } \\
\text { Conclusions of the study: Both interventions } \\
\text { improved Health Related Quality of Life } \\
\text { (HRQoL) scores in women with PCOS without } \\
\text { pre- of active living ( } r=0.39 \text { ) and healthy eating } \\
\text { ( } r=0.53 ; p<0.03\end{array}$ \\
\hline McNamara ${ }^{(19)}$ & $\begin{array}{l}\text { Online Weight } \\
\text { Training }\end{array}$ & $\begin{array}{l}\mathrm{N}=79 \\
\text { students } \\
\text { ( } 58 \text { men and } \\
21 \text { women) }\end{array}$ & 16 weeks & $\mathrm{RCT}$ & $\begin{array}{l}\text { Both online and offline training have improved } \\
\text { knowledge } p<0.05 \text {. }\end{array}$ \\
\hline Ebert $^{(8)}$ & $\begin{array}{l}\text { Internet- } \\
\text { based stress } \\
\text { management } \\
\text { intervention } \\
\text { (iSMI) }\end{array}$ & $\begin{array}{l}\mathrm{N}=263 \\
188 \text { women } \\
\text { and } 75 \text { men } \\
97 \text { women } \\
\text { with iSMI }\end{array}$ & $\begin{array}{l}7 \text { weeks } \\
\text { and } 6 \\
\text { months } \\
\text { follow up }\end{array}$ & $\mathrm{RCT}$ & $\begin{array}{l}\text { iSMI group has greater reduction in perceived } \\
\text { stress at } 7 \text { weeks }(d=0.96,95 \% \mathrm{Cl}: 0.70 \text { to } 1.21) \\
\text { and to the } 6 \text {-month follow-up }(\mathrm{d}=0.65,95 \% \mathrm{Cl} \text { : } \\
0.40 \text { to } 0.89) \text {. }\end{array}$ \\
\hline Woerden (20) & $\begin{array}{l}\text { Web based } \\
\text { tool for } \\
\text { general health } \\
\text { and mental } \\
\text { well-being of } \\
\text { healthcare }\end{array}$ & $\begin{array}{l}\mathrm{N}=1,313 \\
1,048 \text { women } \\
\text { and } 265 \text { men }\end{array}$ & 20 weeks & $\mathrm{RCT}$ & $\begin{array}{l}\text { Self-reported pre-post data on their general } \\
\text { health status improved in } 35.3 \% \text { ( } n=122, p \\
=0.001) ; \text { mental health status improved in } \\
33 \%(n=110, p=0.02) ; \text { reported fruit and } \\
\text { vegetable consumption ( } 7 \text { day recall) increased } \\
(p=0.001) \text {; average time spent on vigorous } \\
\text { exercise increased from } 40.6 \text { minutes/week to } \\
67.6 \text { minutes/week }(p=0.001) \text {. }\end{array}$ \\
\hline $\begin{array}{l}\text { Anderson- } \\
\text { Bill(21) }^{(21)}\end{array}$ & $\begin{array}{l}\text { Web-based } \\
\text { Guide to Health } \\
\text { (WB-GTH); } \\
\text { Nutrition, } \\
\text { physical activity, } \\
\text { and weight } \\
\text { watcher }\end{array}$ & $\begin{array}{l}\mathrm{N}=963 \\
\text { Women } 803\end{array}$ & 8 days & $\mathrm{RCT}$ & $\begin{array}{l}\text { Participants with high self-efficacy tend to } \\
\text { have gained self-regulation towards nutrition } \\
\text { choices and physical activity } p<0.001 \text {. }\end{array}$ \\
\hline
\end{tabular}

study. This problem is due to the accessibility gap and the content of the material. These conclusions can be found in the previous studies that are described in Tables 1 and 2. ${ }^{15,19}$ One of the solutions to overcome the problem of knowledge gap among the society is to provide more accessible information in both online and offline platforms. The online platforms that are mostly used in Indonesia include Instagram, Twitter, Facebook, TikTok, and WhatsApp. ${ }^{11}$ On the other hand, offline methods such as conventional television programs might be a solution to influence more participants to be involved in health programs. ${ }^{22}$ Mass media campaigns aired both on television and online can actually promote either negative and positive attitudes toward dietary habits and physical activity. ${ }^{21,23}$

The impact of mass media campaigns both online and offline can influence people both by direct and indirect pathways throughout the population behavior. Most programs, both e-health promotion and wellness education, can directly influence cognitive and emotional responses of watchers and even provoke a decision-making process at the individual level. This statement was demonstrated in previous studies by Anderson in 2011, Ebert in 2016, and Woerden in 2014 that showed an improvement 
of knowledge and behavior through their e-wellness programs. $^{8,20,21}$

One example of negative impact of mass media campaign is the high rate of advertisement of junk food which can alter the food decisions of households to choose more fattening food. Conversely, the antismoking campaign such as the information of negative impact of smoking can change people's perspective of smoking. ${ }^{24}$ The indirect pathway of mass media campaigns can also influence the behavior of target populations. Some issues both online and offline can increase the interaction of interpersonal discussion. For instance, the study of Ahmed in 2020 shown that some people might potentially consider that COVID-19 is a part of the $5 \mathrm{G}$ conspiracy as a result of the lack of evidence-based information. ${ }^{14}$ On the other hand, Vandormael in 2020 tried to focus on spreading trustworthy information by providing reliable resources of health promotion program using online health videos to promote hygiene information as a way to stop the transmission of the COVID-19. ${ }^{16}$ Furthermore, the influence of e-health promotion programs can impact the knowledge and the behavior of society. For example, the alteration of knowledge and attitude can be influenced by watching 'stay at home' promotions during COVID-19 which have divided people into several groups who either support the campaign and who do not. The debate might improve the interaction of individuals to improve their knowledge from different perspectives and promote stakeholders to create a health policy to prevent any misleading information. The successful health campaign can be defined by some elements such are the message of the campaign, the content of the material, the stakeholders, the influencers, and the participation of the population. ${ }^{22,23}$

When considering the target consumers of soap operas, ${ }^{25}$ the COVID-19 pandemic situation has led to increased time to watch shows on both television and the Internet. The health promotion programs actually can be inserted before or in the middle of these soap operas and serial television shows to provoke more audience to be influenced by the content of health promotion programs. The successful intervention using mass media for Internet-based health programs such as described by Anderson-Bill in 2011 in Table 2 can be mixed with other programs including advertisements or influencer endorsements of healthy life styles by Youtuber favorites or even celebrities. ${ }^{21} \mathrm{~A}$ challenge that offers rewards such as money, incentives or even scholarship programs could increase the enthusiasm of young people especially women to participate and be successful in the health promotion campaigns. ${ }^{4}$ A national healthy diet and indoor exercise program can also be applied in the plot of the story in the Internet serial soap operas, short story movies and online television shows with wide audience base.

Other examples of exercise programs such as simple gymnastic movements, indoor walking, or a dance in the middle of the program both on the Internet and television could overcome the sedentary lifestyle that happens as an effect of the 'stay at home' rule during the pandemic. Nowadays, online platforms such as YouTube and TikTok have significant influence on youngsters. The health promotion content in China on the TikTok platform has the most viewed status by the audience. We concluded that TikTok or YouTube can be used to spread the health messages towards online audiences. Furthermore, a short dance challenge on the TikTok application might even have some contribution to increase physical activity. ${ }^{26}$ The diet trend also can be influenced by the plot story of soap operas, advertisements, or celebrity endorsements. Thus, we as health practitioners should contribute to create and promote those programs to be easily implemented in the community-based sector by following the trendy platforms. Beside using trendy platforms as promoters of a health campaign for youngsters, Meinert in 2020 provided an example of how researchers also created a platform that was more user-friendly among elderly people to promote virtual social interaction between the elderly and their relatives to promote a healthy lifestyle during the pandemic. ${ }^{18}$

Mental health is also negatively affected by the COVID-19 pandemic. Lin in 2020 found that anxiety levels of populations in China are increased during the pandemic. ${ }^{15}$ Yet, online program could be used as a tool to promote stress management among the society impacted by the pandemic situation. For example, Ebert in 2016 found that selfguided iSMI is an effective online program that can 
decrease the stress among participants. ${ }^{8}$ This finding provides an excellent example that online stress interventions can be a solution to overcome mental health problems that might be increased during the COVID-19 pandemic without direct contact between health practitioners and society which can help stop the transmission of COVID-19.

Due to COVID-19 related health problems that have affected most of society, proper integrative methods are needed. We suggest another option beside e-program and television-based programs, which is the adaptation concept of utilizing health information by cadres with a modification by the recruitment of millennial cadres that are expected to help disseminate health information in the surrounding environment. This method has been implemented since the establishment of the Integrated Service Post or 'Pos Pelayanan Terpadu' (Posyandu) in 1986 by involving women volunteers in the surrounding areas of a community. ${ }^{27}$ The advantage of recruiting millennial cadres is that they tend to be more agile, up-to-date concerning new information, and have relatively more time to devote to this work because they are not too involved in household affairs. This approach is also supported by the 'work from home' program during the pandemic which gives them flexibility in time management. ${ }^{28-31}$

The utilization of this millennial cadre and online application could also support government programs such as the PeduliLindungi launched by Ministry of Communication and Information Technology. PeduliLindungi is aimed to track a user's contact history with a gadget base which will be useful if someone is suspected of being exposed to COVID-19. ${ }^{31}$ Millennial cadres with the assistance of health cadres and influential people are expected to be human messengers to socialize PeduliLindungi and COVID-19 protocols, and provide proper information related to COVID-19. They will have access to the COVID-19 Response Acceleration Task Force in related areas to gain the right information. Millennial cadres will be the right person to get confirmation about the various information spreading in the community to attenuate any hoax deployment. They are also tasked with reporting suspicious cases in their working area. In addition, it is hoped that the millennial cadres will motivate and supervise people to be more disciplined in maintaining a healthy lifestyle and applying the COVID-19 protocols in daily life.

In the case of recruiting millennial cadres as a part of surveillance, rewards and work motivation are very important for any organization, as these can be used to direct the staffs towards achieving the goals of the organization. Asaari in 2019 showed that there are positive and significant relationships between rewards and motivation..$^{32}$ Another study by Nuraya in 2017 concluded that the working environment and salary have significant influence on motivation and motivation can significantly influence a person's job satisfaction..$^{33}$ Those data describe a realistic view about the importance of budget funds for multisectoral workers related to COVID-19 management.

\section{Conclusion}

In conclusion, the Internet-based information health system has a potential impact in spreading health related information such as COVID-19 understanding and wellness education to the society. The implementation of Internet-based health promotion programs was found to be an effective method to overcome misleading information. In addition, online methods also can be used as a solution to educate and to promote healthy eating, exercise, and stress management. Internet-based methods not only require the accessibility of Internet, gadgets, platforms, and participation of certain stakeholders and influencers, but also need good quality of the content which is presented to the society. Beside the positive effects of digitalization, we have be concerned about the knowledge gap and accessibility of the Internet users in Indonesia. Thus, we suggest not only the use of television programs but also the integrative method of excellent online programs and utilization of millennial cadres for certain population categories to spread the proper health information without dependency on Internet access.

\section{Acknowledgement}

This work was supported by the Biomedical Sciences Department, Faculty of Medicine, Padjadjaran University, Bandung, Indonesia and Physiology Department, Faculty of Medicine, Jenderal Achmad 
Yani University, Cimahi, Indonesia.

\section{References}

1. Abrams EM, Szefler SJ. COVID-19 and the impact of social determinants of health. Lancet Respir Med. 2020;8(7):659-661.

2. World Health Organization. WHO Coronavirus Disease (COVID-19) Dashboard. 2020. [Internet]. Available at: https://covid19. who.int/?gclid=CjwKCAjwztL2BRATE iwAvnALcpJvfJoB 2ZO9AW4cscOjOP puNNisqVVITkpdsIGJOuXSFkrhb LCafxoCjBOQAvD_BwE

3. Puskakom Universitas Indonesia. Profil Pengguna Internet Indonesia [internet]. Jakarta: Universitas Indonesia; 2017 [updated 2017; cited 2020 May]. Available from: http://puskakom. ui.ac.id/wp-content/uploads/2017/01/SurveyAPJII-2014-v2.pdf

4. Black S, Allen JD. Part 7: Rewards, motivation, and performance. Ref Libr. 2018;59(4):205-18.

5. Sartorius N. Meanings of health and its promotion. Croat Med. 2006;89:539-48.

6. Farhud DD. Impact of life-style on health and physical capability: a data mining approach. ACM Int Conf Proceeding Ser. 2018;2018-March(11):119-24.

7. Kazemi M, McBreairty LE, Zello GA, Pierson RA, Gordon JJ, Serrao SB. A pulse-based diet and the therapeutic lifestyle changes diet in combination with health counseling and exercise improve health-related quality of life in women with polycystic ovary syndrome: secondary analysis of a randomized controlled trial. J Psychosom Obstet Gynecol. 2020;41(2):144-53.

8. Ebert DD, Heber E, Berking $M$, Riper $H$, Cuijpers $P$, Funk B. Self-guided internet-based and mobilebased stress management for employees: results of a randomised controlled trial. Occup Environ Med. 2016;73(5):315-23.

9. Guerrero $M D$, Vanderloo LM, Rhodes RE, Faulkner G, Moore SA, Tremblay MS. Canadian children's and youth's adherence to the 24-h movement guidelines during the COVID-19 pandemic: a decision tree analysis. J Sport Heal Sci. 2020;9(4): 313-321.
10. Daryanti S, Simanjuntak KU. Segmentation of mobile internet users in the Indonesian context: insight for mobile internet product development management. South East Asian J Manag. 2016;10(1).

11. Müller J. Internet usage in Indonesia - Statistics \& Facts. Internet usage in Indonesia [Internet] Statistics \& Facts. 2019. [updated 14 Oct 2020; cited 2020 May] Available at: https://www. statista.com/topics/2431/internet-usage-inindonesia/

12. Oren O, Yang EH, Gluckman TJ, Michos ED, Blumenthal RS, Gersh BJ. The use of chloroquine and hydroxychloroquine in COVID-19 and cardiovascular implications: understanding safety discrepancies to improve interpretation and design of clinical trials. Circ Arrhythmia Electrophysiol. 2020;13(6):586-90.

13. Howard J, Huang A, Li Z, Tufekci Z, Zdimal V, Westhuizen $\mathrm{H}-\mathrm{M}$ van der. Face mask against COVID-19: an evidence review. $\mathrm{Br}$ Med J. 2020:1-8.

14. Ahmed W, Vidal-Alaball J, Downing J, Seguí FL. COVID-19 and the $5 \mathrm{G}$ conspiracy theory: social network analysis of Twitter data. J Med Internet Res. 2020;22(5):1-9.

15. Lin $\mathrm{Y}, \mathrm{Hu} \mathrm{Z}$, Alias $\mathrm{H}$, Wong LP. Knowledge, attitudes, impact, and anxiety regarding COVID-19 infection among the public in China. Front Public Heal. 2020;8:236.

16. Schillinger D, Chittamuru D, Ramírez AS. From "Infodemics" to health promotion: a novel framework for the role of social media in public health. Am J Public Health. 2020;1-4.

17. Vandormael A, Vandormael A, Adam M, Greuel $M$, Bärnighausen $T$, Bärnighausen T. A short, animated video to improve good COVID-19 hygiene practices: a structured summary of a study protocol for a randomized controlled trial. Trials. 2020;21(1):21-3.

18. Meinert E, Milne-Ives M, Surodina S, Lam C. Agile requirements engineering and software planning for a digital health platform to engage the effects of isolation caused by social distancing: case study. JMIR Public Health Surveill. 2020;6(2):e19297.

19. McNAmara JM, Walm RILS, Tearne DAJS, Ovassin 
TRMC. Online weight training. J Strength Cond Res. 2008;22(4):1164-8.

20. Van Woerden HC, Ashton K, Garlick C, Hurley A, Cooper A, Willson A. Evaluation of a web based tool to improve health behaviours in healthcare staff. Int Arch Med. 2014;7(1):1-9.

21. Anderson-Bill ES, Winett RA, Wojcik JR. Social cognitive determinants of nutrition and physical activity among web-health users enrolling in an online intervention: the influence of social support, self-efficacy, outcome expectations, and self-regulation. J Med Internet Res. 2011;13(1):1-16.

22. Burzyńska J, Binkowska-Bury $M$, Januszewicz $P$. Television as a source of information on health and illness - review of benefits and problems. Prog Heal Sci. 2015;5(2):174-84.

23. Berry TR, Spence JC, Plotnikoff RC, Bauman A, McCargar $L$, Witcher $C$, et al. A mixed methods evaluation of televised health promotion advertisements targeted at older adults. Eval Program Plann. 2009;32(3):278-88.

24. Freisling $\mathrm{H}$, Haas $\mathrm{K}$, Elmadfa I. Mass media nutrition information sources and associations with fruit and vegetable consumption among adolescents. Public Health Nutr. 2010;13(2):26975.

25. Syed MAM. Soap opera as a site for engaging with modernity amongst Malay women in Malaysia. Malaysian J Media Stud. 2015;13(2011):17-36.

26. Zhu C, Xu X, Zhang W, Chen J, Evans R. How health communication via tik tok makes a difference: a content analysis of TikTok accounts run by Chinese provincial health committees. Int J Environ Res Public Health. 2020;17(1):1-13.

27. Paramita VS, Isnayati I, Ikrawan Y, Adialita T. Secercah hati: community empowerment program in health and economic affairs through the role of Posyandu and Posbindu. M J Pemberdaya Masy. 2019;3(2):151-63.

28. Menteri Ketenagakerjaan Republik Indonesia. Surat Edaran Menteri Ketenagakerjaan RI Nomor M/2/HM.01/III/202. Panduan Tindak Lanjut Terkait Pencegahan Penyebaran Corona Virus Disease 2019 (COVID19) Di Lingkungan Kementrian Ketenagakerjaan. 2020.
Kebijakan Pegawai Bekerja Dari Rumah (Working From Home) - Pusdiklat Pegawai Kementerian Pendidikan dan Kebudayaan. 2020.

30. Anggara S, Afiyah S, Farida AS, Muslim J. Inovasi Kebilakan PUublik Tentang Pencegahan dan Penanggulangan Corona Virus Disease 19 (COVID-19) di Jawa Barat. 2020.

31. Kemkominfo. PeduliLindungi. 2020. [Internet]. Available from: https://pedulilindungi. id/\#tentang

32. Asaari MHAH, Desa MN, Subramaniam L. Influence of salary, promotion, and recognition toward work motivation among government trade agency employees. Int J Bus Manag. 2019;14(4):48.

33. Nuraya AS, Pratiwi D. The effect of work environment and salary on motivation and the impact on employee job satisfaction in Indonesia Tourism Development Corporation (Persero). J Ilmu Manaj Ekon. 2017;9(2):122.

29. KEMENDIKBUD. Pusdiklat Memberlakukan 